Scenes from Postgraduate Life

\title{
A significant change in direction for the National Association of Clinical Tutors
}

This was the week that saw the headlines 'Government says: Sell ancestral homes to the nouveau riche - no more grants for the 'ancient pauvre', 'Minister backs taking nurses to court over regrading disputes'. The 1988 winter meeting of the National Association of Clinical Tutors (NACT) was held at the University Hospital of Wales, which was not crumbling nearly as much as press reports of construction faults had led one to believe it might be. To your correspondent the centre of Cardiff seemed to have shed its inner decay only to remain surrounded by housing which has utterly failed to match the transition from Edwardian squalor to the working class 'yuppiness' of so many industrial cities. The meeting was, therefore, held against a backdrop of foreboding, angst and hiraeth (a Welsh concept, almost untranslatable but roughly meaning a longing for an idealized homeland).

The main NACT meeting was preceded by a day and a half 'think tank' devoted to helping doctors with their careers. Early on it became clear that 'counselling' often meant 'apologizing' in some sort of general way for the awfulness experienced by 'stuck' and career junior doctors that we older doctors have witnessed. We have not been able to help what has happened any more than enlightened Russian aristos could help the Red Revolution. The Association chairman, Dr Gifford Batstone (chemical pathologist, Salisbury) opened with some results from a survey of clinical tutors which showed that doctors were to be considered 'stuck' when they had been a senior house officer (SHO) for 3 years, a registrar for 4-5 and a senior registrar for 6 years; 7 out of 10 clinical tutors thought 'advice' or 'guidance' (as distinct from counselling) should be given by the junior doctor's own consultant. Unfortunately, the Government's document Achieving a Balance closely links 'counselling' with making the 'correct' career choice and with the concept of 'stuck' doctors; implicit in this is a suspicion that when 'Achieving a Balance' does not work (which it never can without extra money) then it will be blamed on failure of proper 'counselling'. Dr Batstone's survey indicated that clinical tutors felt that there should be some form of regular career counselling of junior doctors and not just opportunistic or crisis counselling when there appeared to be a special need.

There was a wide divergence of opinion as to who should be responsible for career counselling, guidance and advising: the choices were the clinical consultant, college tutor, clinical tutor, postgraduate dean or specialty regional adviser. Clinical tutors on average expected that there would have to be 'protected time' of almost 5 hours per week (although in larger districts it may require as much as $\mathbf{2}$ days a week) in order to adequately and regularly counsel junior doctors. Bearing in mind that clinical tutors have full clinical responsibilities there would have to be commitment by government to negotiate a mechanism for relieving clinical tutors of a proportion of their clinical duties for the duration of their tutorship. Mr K. Pagliero (thoracic surgeon, Exeter) the secretary of the Association, reinforced the prevalent view that junior doctors had a right to expect their seniors to move more quickly towards a decent career structure and suggested that the training log books, which all junior doctors should have, should contain details of regular interviews with both the college tutor and clinical tutor. Unhappily, 'Achieving a Balance' means in practice that some groups of clinical consultants will have to accept that as a group they are likely to lose registrars who may or may not be replaced by SHOs?

The working model for systematic career counsell ing was introduced by Dr Rosemary Mulligan (ches physician and postgraduate dean, East Anglian Region) whose industry and enthusiasm put her among the 'super women'. These are the women whose very existence must be a discouragement to the average young lady doctor who must feel that she could not possibly aspire to such dedication and therefore not even make the attempt to combine a proper main stream medical career with child-bearing. Dr Mulligan introduced us to the concept of 'career tubes' (not any longer 'career triangles' with consultants at the apex). She explained that she had introduced career counselling for all junior doctors by all clinical tutors in her region; that this was explained in the job description given to each doctor; data bases or $\log$ books were kept of career and personal details of all junior doctors. The assessment of junior doctors included details of study leave and further study leave was conditional on a 'study leave debriefing' by the clinical tutor. In addition the clinical tutor has to sign all requests for study leave by junior doctors (something which seems to be becoming more widespread). It was emphasized that one important aspect was 'feedback' from the clinical tutor and consultant to the junior doctor. It was one of the recurring themes of the meeting that consultants were bad at not telling

(C) The Fellowship of Postgraduate Medicine, 1989 
their juniors their good and bad points and not putting aside protected time to teach and give guidance to juniors.

Mr Charles Dobson of the Department of Health (now severed from Social Security) gave a useful (but idealistic) account of how the Department predicts the numbers of likely vacancies in all specialties. There are, of course, several models but all of them depend on the government and Health Department being able to persuade Regions to accept expansion of the consultant grade, especially in the shortage specialties, and even in the first year the much vaunted $2 \%$ expansion of the consultant grade has not happened. An earlier and seemingly sensible statistic has had to be abandoned, namely details of the number of applicants for vacant consultant posts - that would probably still be the simplest and most reliable indicator for junior doctors of job prospects. Now we have to rely on more sophisticated adjustments of the familiar senior registrar outputs and predicted consultant vacancies. However, $\mathrm{Mr}$ Dobson was an enthusiastic and thoughtful exponent of his formulae. One must not be too cynical otherwise there is no progress. The sources of manpower data are shown in Table I.

One of the most progressive and indeed almost revolutionary deans is Ron King (ex-general physician, Tonbridge, now postgraduate dean, South East Thames Region). He has produced a "Career Journal' which is a very detailed log book for preregistration house officers. This is to be tried in SE Thames and Mersey and will implicitly amount to a 'learning contract'. If successful this 'contract' will be used by all grades of junior staff. It will contain details of dates of career counselling and will be available for College visitors. This will go a long way to addressing one of the most intractible of problems for clinical tutors - that of doing something about consultants who do not teach and who exploit their junior staff.

Dr Allan Nye (educationalist, NHS Training Authority) introduced us to the concept of 'working to live' or 'living to work'. Junior doctors live to work and often have little spare time, as shown by inability to pursue outside interests and regret at having chosen medicine as a career.

The full meeting of the National Association of Clinical Tutors started with a useful 'lecture' from $\mathrm{Dr}$ Alistair Donald (regional adviser in general practice, SE Scotland). He pointed out that review of the educational literature had shown that no single method of postgraduate medical education had been shown superior in altering clinical behaviour. Interestingly, reading at home is the general practitioners' favourite form of postgraduate medical education irrespective of the distance the GP lives from the Postgraduate Centre. He indicated an increasing trend for larger group practices to break up because of 'constraints of the older doctor'. He speculated on the effects of again paying GPs postgraduate allowances for educational activities and on the introduction of periodical reaccreditation of doctors as happens in the United States of America.

Dr Donald expressed his anxiety about the lack of vocational training posts in general medicine and pointed out that less than $40 \%$ of vocational trainees had experience in a general medical post - this was

Table I Sources of manpower data

\begin{tabular}{lll}
\hline Data source & Main contents & Available from: \\
\hline $\begin{array}{l}\text { 1. National } \\
\text { tables }\end{array}$ & $\begin{array}{l}\text { Staff in post and vacancies for HCHS medical and } \\
\text { dental staff analysed by specialty, grade, age, sex, } \\
\text { time in grade, country of birth (E\&W) }\end{array}$ & $\begin{array}{l}\text { SR7A division, DoH, Hannibal House, Elephant } \\
\text { and Castle, London SE1 }\end{array}$ \\
$\begin{array}{l}\text { 2. } \begin{array}{l}\text { Time } \\
\text { series } \\
\text { tables }\end{array} \\
\begin{array}{l}\text { Time series of some of the information in (1) } \\
\text { (E\&W) }\end{array}\end{array}$ & As above \\
$\begin{array}{l}\text { and } \\
\text { leavers' } \\
\text { tables }\end{array}$ & $\begin{array}{l}\text { Flow data on registrars, senior registrars and con- } \\
\text { sultants by specialty (E\&W) }\end{array}$ & $\begin{array}{l}\text { Not generally available, but enquiries to SR7A } \\
\text { as above }\end{array}$ \\
$\begin{array}{l}\text { 4. 'Health } \\
\begin{array}{l}\text { Trends' } \\
\text { article }\end{array}\end{array}$ & Selection of data from (1) to (3) & $\begin{array}{l}\text { Annual article in 'Health Trends' (normally May } \\
\text { edition), HMSO }\end{array}$ \\
$\begin{array}{l}\text { 5. JPAC } \\
\text { reports }\end{array}$ & $\begin{array}{l}\text { Judgements of the JPAC on future trends in con- } \\
\text { sultant growth by specialty (E\&W) }\end{array}$ & $\begin{array}{l}\text { 1986 and 1987 reports from MME Division, } \\
\text { Room 411, Eileen House, Newington Causeway, } \\
\text { London SE1 }\end{array}$ \\
\hline
\end{tabular}

E \& W = England and Wales. 
disquieting because general medicine has been shown to be the hospital discipline most relevant to general practice. Dr Donald emphasized that distance learning was important but he was refreshingly in favour of short didactic lectures.

Dr Pene Owen (Department of General Practice, University Hospital of Wales) introduced her survey of general practice postgraduate education which confirmed that three-quarters of practices held drug company meetings but under half held other regular meetings organized by general practitioners.

Dr K.G. Hardy (GP tutor, Cardiff) gave a most useful overview of so-called distance learning techniques, particularly the role played by the Open University, British Medical Television, Eurotransmed and linked tele-conferencing.

Undoubtedly, the high spot of the NACT winter meetings is the address by the Chief Medical Officer or his deputy - this is always titled 'Matters of Moment' which does lead one to speculate whether all matters of moment have to be momentous. Certainly this year the items raised by Dr R.M. Oliver (Sir Donald Acheson's Deputy) all seemed just that. Dr Oliver had an almost impossible task. He had to convey unpalatable government thoughts and by the nature of his job he had to do so impartially - it was a masterly performance - never did he by an altered intonation or grimace indicate whether he approved or disapproved of the substance of what he was saying. Even so he left one with the impression that he was a compassionate and sensible man. One of the 'understandings' of this talk is that it is 'off the record'; among the topics he raised were:

1. The fact of the recent separation of the Departments of Health and Social Security.

2. The forthcoming white paper of the NHS review.

3. 'Achieving a Balance' and the need to convince regions to expand consultant numbers while still working within available resources.

4. Development of medical audit which must be more than 'grand rounds' and death and disaster meetings and should be 'a systematic, critical evaluation of medical activity'.

5. Standing Committee on Postgraduate Medical Education (SCOPME) which replaces the now defunct Central Council for Postgraduate Medical Education for England and Wales. This will produce its recommendations and then consult instead of consulting first and then making recommendations. The old CPME seldom did produce the consensus it was supposed to and used to be frequently circumvented by powerful lobby groups which did not agree with the consensus.

The National Advice Centre will be transferred to the British Council and the House Officer Safety Net Scheme to the Department of Health.
The Annual General Meeting of the Association was businesslike and produced two fundamental and overdue innovations. The first was finally to agree that the Postgraduate Medical Journal should be the 'official' journal for reporting meetings and news of the Association. For several years the Postgraduate Medical Journal has carried occasional brief reports of NACT meetings. However, now it has been agreed that all members of NACT will receive the monthly Postgraduate Medical Journal at cost price and the subscription tutors pay to the NACT will cover the cost of them receiving the Journal. The second important decision of the AGM concerned distinction awards - for many years it was perceived that being a clinical tutor increased the chances of receiving a merit award. However, it has gradually become clear that this may not be the case. Tutors thought that as the Greeks used to punish the messenger who brought bad news so tutors who have to introduce uncomfortable audit, unpleasant tidings about 'Achieving a Balance' and plans for ensuring juniors have a proper record of learning, teaching and counselling experience may not be the most popular consultants in their district. The proposition accepted by the meeting was that the names of a number (probably about a dozen) of clinical tutors would be forwarded to the Central Awards Committee (one tutor asked why the names of all tutors should not be submitted!). This would be done in conjunction with the UK Deans through $\mathrm{Dr}$ Ron King. Dr C.D.R. Pengelly (general physician, Altringham) the doyen of clinical tutors, proposed that Dr King and Dr I.J.T. Davies (general physician and Regional Director of Postgraduate Medical Eduction, Inverness) would co-ordinate the names and the exact mechanism would be decided by the NACT Council.

Other topics at the AGM included closer links with the National Association of Medical Centre Administrators (NAPMECA), Associate membership of the Association and the attitude of the Association to having GP (as opposed to other specialty) tutors on the council of the Association.

The afternoon was somewhat easier going - the after lunch slot was the report by this year's Wyeth fellow to the United States, Dr Irving Cobden (Gastroenterologist, $\mathrm{N}$. Tyneside) who gave an amusing and informative glimpse of the use of computers in the hospitals he visited in North Carolina in a talk entitled 'Chips with Everything'.

We then divided into groups in which we again considered medical audit and many of the problems of introducing it. Some hospitals such as Chesterfield, already have an 'audit co-ordinator' whose job it is to ensure that there is meaningful peer review. Several tutors expressed the view that stringent (and threatening) forms of audit were inevitable and it would be better to anticipate rather than resist and form in each 
district small groups of consultants who would be responsible for introducing forms of audit likely to be acceptable to consultant colleagues as well as to the Government (and the people).

The Royal College of Physicians of London and the Joint Committee on Higher Medical Training have already anticipated that the government is going to expect a more stringent form of audit and has suggested that hospitals should keep records of proper audit type facilities and there is even an implication that attendance by consultants will be rewarded (possibly by merit awards?):

2. Visiting teams will enquire about the existence of procedures for clinical review in all hospitals. The usual clinical meeting or 'grand round', while desirable, is not sufficient to meet the requirements of clinical audit because of the non-random selection of patients, a bias towards unusual medical conditions and, often, the lack of attention to administrative and communication matters. We recommend a regular review meeting to discuss the investigation, treatment and management of individual patients preferably those recently discharged - by individual consultants or firms, to be held in the presence of fellow consultants and junior doctors. Occasional meetings could review the management of specific conditions within the hospital. Each medical division should appoint a consultant to be responsible for the organization and functioning of these meetings.

3. A special time should be set aside for the meetings. Records of meetings including a record of the number of consultants and others attending should be made available when hospital posts are being evaluated. It will be stressed that these procedures have an important educational benefit which would be taken into account in assessing the training value of posts. Approval of a post might be withheld if adequate clinical review meetings are not held. Secretarial and other assistance will be needed for the organization of meetings and other audit procedures, and financial support may have to be sought from Health Authorities.

Mr H.L. Young, senior lecturer in Surgery, University of Wales College of Medicine, spoke about Eurotransmed which will be a system of postgraduate medical education television programmes in English building on the American experience of medical television (two of which are coded and one of which is open to all viewers). The project is being co-ordinated at the University of Leyden and should be operational by 1990 .

The final session was by an educationalist from Nottingham, Dr George Brown, who addressed the problem of adult learning. He developed several themes important for adult learning, namely, 'Knowing thyself', the importance of being able to integrate new with old knowledge, and the significance of 'relevance' in adult learning. For those who wish for more information on this topic which is of great relevance to clinical tutors it is worth reading $\mathrm{Dr}$ Brown's own book [Brown, G.A. and Aitken, M.J. (1988): Effective Teaching in Higher Education, London, Methuen].

It was a thoughtful few days. I felt we were getting glimpses of the future in which consultant practice as presently conceived is doomed. The problem is do we appease, go for damage limitation or oppose outright? There are such strong pressures for change from within the profession as well as from Government, that we have no realistic alternative but to co-operate. I left Cardiff with more foreboding, angst and hiraeth than I arrived with. I fear for 1989.

\section{Conclusions}

This was an unusually productive NACT winter meeting and the important items for clinical tutors to note are:

1. The role of clinical tutors in the introduction soon of some form of rather unpleasant audit of clinical performances and we had better hurry to put our house in order or else ...

2. The profession had better do more about accepting 'Achieving a Balance' otherwise clinical tutors may take the blame when it is not working and again government may step in.

3. The Association has taken two great steps to professionalize itself:

a) It has established a central secretariat.

b) It has a regular established journal for keeping itself informed about itself.

4. The NACT has recognized that it, like the Royal Colleges, has the right and obligation to submit recommended names to the Central Merit Awards Committee.

5. Consultants will have to devote more time to formally teaching their juniors meaningful and regular feedback of their performances and to accept that their own performance too will be increasingly scrutinized.

6. There remain outstanding issues such as 'protected time' for the duties of being a clinical tutor and a proper rate of remuneration.

I.J.T. Davies, F.R.C.P., F.R.C.P. Edin.

Regional Director of Postgraduate Medical Education, Highlands and Western Isles, Postgraduate Medical Centre, Raigmore Hospital, Inverness IV2 $3 U J$. 